\title{
MOLECULAR EVOLUTION OF GPCRS Ghrelin/ghrelin receptors
}

\author{
Hiroyuki Kaiya, Kenji Kangawa and Mikiya Miyazato
}

Department of Biochemistry, National Cerebral and Cardiovascular Center Research Institute, 5-7-1 Fujishirodai, Suita, Osaka 565-8565, Japan

Correspondence should be addressed to H Kaiya Email kaiya@ncvc.go.jp

\begin{abstract}
After the discovery in 1996 of the GH secretagogue-receptor type-1a (GHS-R1a) as an orphan G-protein coupled receptor, many research groups attempted to identify the endogenous ligand. Finally, Kojima and colleagues successfully isolated the peptide ligand from rat stomach extracts, determined its structure, and named it ghrelin. The GHS-R1a is now accepted to be the ghrelin receptor. The existence of the ghrelin system has been demonstrated in many animal classes through biochemical and molecular biological strategies as well as through genome projects. Our work, focused on identifying the ghrelin receptor and its ligand ghrelin in laboratory animals, particularly nonmammalian vertebrates, has provided new insights into the molecular evolution of the ghrelin receptor. In mammals, it is assumed that the ghrelin receptor evolution is in line with the plate tectonics theory. In contrast, the evolution of the ghrelin receptor in nonmammalian vertebrates differs from that of mammals: multiplicity of the ghrelin receptor isoforms is observed in nonmammalian vertebrates only. This multiplicity is due to genome duplication and polyploidization events that particularly occurred in Teleostei. Furthermore, it is likely that the evolution of the ghrelin receptor is distinct from that of its ligand, ghrelin, because only one ghrelin isoform has been detected in all species examined so far. In this review, we summarize current knowledge related to the molecular evolution of the ghrelin receptor in mammalian and nonmammalian vertebrates.
\end{abstract}
Key Words
- ghrelin
- ghrelin receptor
- GHS-R
- GHS-R-like receptor

Journal of Molecular Endocrinology (2014) 52, T87-T100

\section{The discovery of growth hormone secretagogue receptor and its endogenous ligand, ghrelin, and ghrelin gene-derived peptides}

Most receptors for peptide hormones are G-proteincoupled receptors (GPCRs). There are still unidentified endogenous ligands for more than 140 GPCRs, and such receptors are termed as orphan GPCRs (Civelli 2012, Tang et al. 2012). Reverse pharmacology has been a successful approach to identify natural ligands, including ghrelin, for many orphan GPCRs (Kojima et al. 1999, Civelli et al. 2006). Ghrelin was identified as an endogenous ligand for the growth hormone secretagogue-receptor (GHS-R) type-1a (GHS-R1a), which was first discovered as an endogenous receptor for the artificial GH-releasing peptide (GHRP; Howard et al. 1996, Tannenbaum \& Bowers 2001).

Actually, Howard et al. (1996) identified two GHS-R molecules with some variation in length, in both humans and pigs. In humans, one of these two is the functional receptor; this one is called the GHS-R1a and consists of 366 amino acids (AAs) with seven transmembrane domains (TMDs 1-7) (Howard et al. 1996). The other type is the alternative splice variant of the GHS-R gene named GHSR1b, which consists of 289 AAs with TMDs 1-5 of GHS-R1a

Published by Bioscientifica Ltd.

This paper is one of eight papers that form part of a thematic review section on the Molecular Evolution of GPCRs. The Guest Editor for this section was Hubert Vaudry European Institute for Peptides Research, University of Rouen, France. 4 . 
and a part of the connected intron. Only the GHS-R1a induces the intracellular $\mathrm{Ca}^{2+}$ signaling that mediates the activation of a G-protein subtype, $\mathrm{G} \alpha_{\mathrm{q} / 11}$, by agonist treatment (Howard et al. 1996, Kojima et al. 1999, Wettschureck et al. 2005). The GHS-R1b does not induce $\mathrm{Ca}^{2+}$ signaling due to the lack of TMDs 6 and 7. Furthermore, the GHS-R belongs to a family with paralogue receptors such as the motilin, neuromedin $\mathrm{U}$, and neurotensin, and still orphan GPCR, GPR39, according to their fundamental structural features (Fig. 1). All ligands for these receptors, including ghrelin, are known to be involved in gastrointestinal functions by binding to its own receptor, but note that the ligand for GPR39 is as yet unknown (Kojima et al. 2005).

Normally, GHS-R1a is considered to form a functional homodimer (Holst et al. 2005). However, a heterodimerization with GHS-R1b has been shown to occur and to reduce the signaling capacity of GHS-R1a (Chan \& Cheng 2004, Leung et al. 2007, Chow et al. 2012), suggesting a dominant-negative role for GHS-R1b in GHS-R1a signaling (Leung et al. 2007). Furthermore, the GHS-R1a can pair with other GPCRs, e.g., melanocortin 3 receptor (MC3), dopamine receptors (D1 and D2), serotonin $2 \mathrm{C}$ receptor (5-HT2C), and somatostatin receptor-5 (SSTR5), or with members of the prostanoid receptor family such as prostacycline receptor, prostaglandin $\mathrm{E}_{2}$ receptor subtype EP3-I, and the thromboxane A2 receptor (see review by Schellekens et al. (2013)). These heterodimerizations will affect ligand selectivity, G-protein coupling, and the downstream signaling of each receptor. Also the GHSR1b can form heterodimers with other GPCRs, e.g., the neurotensin receptor 1 (Takahashi et al. 2006).

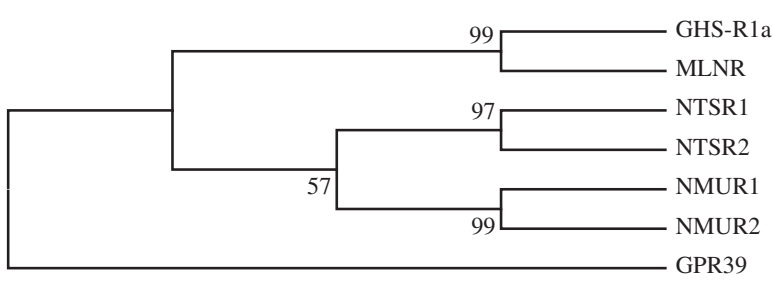

\section{Figure 1}

Molecular phylogenetic tree of the ghrelin receptor (GHS-R1a) family in humans. The phylogenetic tree of amino acid (AA) sequences was constructed by using the neighbor-joining (NJ) method with MEGA4 (http://www.megasoftware.net/). The numbers on the branch points are the bootstrap values (as percentages based on 1000 replicates). AA sequences obtained from the NCBI BLAST (http://blast.ncbi.nlm.nih.gov/ Blast.cgi). Abbreviations and accession numbers indicate as follows: MLNR: motilin receptor (NM_001507), NMUR1 and 2: neuromedin-U receptor 1 and 2 (NM_006056 and NM_020167), and NTSR1 and 2: neurotensin receptor 1 and 2 (NM_002531 and NM_012344), and GPR39 (NM_001508).
Mammalian ghrelin generally consists of 28 AAs (Kojima et al. 1999), but the number of constituting AAs varies when nonmammalian vertebrates are included: 16 AAs in the elasmobranch stingray, 25 AAs in sharks, 17-23 AAs in teleosts, 27-28 AAs in amphibians, 25 AAs in a reptilian turtle, and 26 AAs in birds (Kaiya et al. 2011a,b). The N-terminal third serine residue of ghrelin is generally acylated with $n$-octanoic acid, and this acyl modification is essential for binding of ghrelin to the GHS-R1a and for eliciting the subsequent ghrelin activities (Kojima et al. 1999, Großauer et al. 2010). However, the acylated AA is substituted with threonine instead of serine in frogs of the genus Rana, and the threonine residue is acylated with $n$-octanoic or $n$-decanoic acid (Kaiya et al. 2001, 2011a,b). Various acyl modifications other than $n$-octanoylation, including various saturated and unsaturated medium-chain fatty acids, have been identified in both mammals and nonmammalian vertebrates (see review by Kojima et al. (2008)). In addition, phylogenetic analyses of ghrelin including both mammals and nonmammalian vertebrates reveal several structural features of ghrelin apart from the variation of the number of constituting AAs: i) high conservation of the N-terminal seven AA sequence, GSSFLSP, across species, ii) great diversity of AA sequence at the $\mathrm{C}$-terminal side after the conserved sequence, iii) glycosylation in addition to acylation of ghrelin in the elasmobranch stingray, and iv) a C-terminal amidation unique for teleosts (see review by Kaiya et al. 2008, 2011b).

Mainly based on mammalian studies, it has been recognized that ghrelin is a multifunctional hormone involved in GH secretion, appetite regulation, neuroendocrine function, cardiovascular functioning, gastroenteropancreatic function, gastrointestinal motility, glucose metabolism, cell differentiation, immune function, bone metabolism, sleep, and the promotion of learning and memory (Diano et al. 2006, Hosoda et al. 2006, Chen et al. 2009, Carlini et al. 2010, Kojima \& Kangawa 2010, Verhulst \& Depoortere 2012). Our main aim is to explore what the general actions of ghrelin are in vertebrates. At present, it has been revealed that GH-releasing ability is a common action among those vertebrates examined so far, although effects on feeding regulation and gastrointestinal motility vary in each animal (see reviews by Kaiya et al. (2013b)). Further studies are required to clarify the fundamental roles of ghrelin in vertebrates.

Three bioactive peptides are generated from the ghrelin precursor: ghrelin, unacylated ghrelin (des-acyl ghrelin), and obestatin (Nishi et al. 2011). Ghrelin is produced by acylation of unacylated ghrelin with the

Published by Bioscientifica Ltd 
specific enzyme ghrelin-O-acyltransferase (Gutierrez et al. 2008, Yang et al. 2008). Unacylated ghrelin is also present in circulating blood and the stomach, and the quantity is much greater than that of ghrelin (Kojima et al. 1999, Hosoda et al. 2000). Unacylated ghrelin exerts some biological actions, e.g., regulate feeding (Asakawa et al. 2005, Toshinai et al. 2006, Inhoff et al. 2009) and gut motility (Fujimiya et al. 2012), a GHS-R1a-independent antagonistic effect on ghrelin-induced insulin secretion and glucose metabolism, a trophic and protective effect on $\beta$-cells, as well as a role in muscle regeneration and in decreasing fat mass (Delhanty et al. 2012, Delhanty \& van der Lely 2013). How does unacylated ghrelin act? It is clear that unacylated ghrelin does not induce an intracellular $\mathrm{Ca}^{2+}$ increase (Kojima et al. 1999). Granata et al. (2010) reported that unacylated ghrelin binds on pancreatic $\beta$-cells with high affinity even though GHS-R1a is not expressed, suggesting possible presence of a yet unidentified specific receptor for unacylated ghrelin.

\section{Mammalian ghrelin receptors and speculation about their receptor evolution}

As the AA sequences of numerous mammalian ghrelin receptors are available from genome sequencing projects, we have constructed a molecular phylogenetic tree based on these sequences (Fig. 2). The analysis shows a high sequence identity (85-95\%) across different mammalian species. In addition, while investigating the regularity, we found that the classification of the mammals into clades on the basis of AA sequence of the ghrelin receptor is in agreement with classifications of the mammals based on plate tectonics theory and DNA sequence (Eizirik et al. 2001, Murphy et al. 2001a,b, Nishihara et al. 2009), although the accuracy of our analysis is still low. In this regard, we found three large groups, i.e., Euarchontoglires, Laurasiatheria, and Marsupialia (Fig. 2). Other than these, there are categories of Afrotheria and Xenarthra in the classifications of mammals based on plate tectonics theory. However, as the numbers of the species for Afrotheria and Xenarthra for which the ghrelin receptor sequences are known are still few, the accuracy of our analysis is low. For example, lesser hedgehog tenrec and African elephant actually belong to Afrotheria, but they were classified into different unexpected clades in this analysis (open squares, Fig. 2). In addition, because only partial sequences for Xenarthra were publicly available, we did not include these data in our analysis. Although more detailed studies are necessary in the future, current data imply that the evolution of the mammalian ghrelin receptor is the consequence of dispersal of animals with the continental drift.

\section{Nonmammalian ghrelin receptors and their isoforms}

In this section, we summarize what is known about the nonmammalian ghrelin receptor today. First, we give a brief description of different kinds and arrangements of nonmammalian ghrelin receptors before discussing their evolution. This is because the ghrelin receptors in nonmammals are more complicated/complex and diverse than in mammals.

Both the ghrelin receptor (GHS-R1a) and the alternative splice variant GHS-R1b are present in nonmammalian species. Unlike GHS-R1b, other alternative splice variants are found in birds, as will be described later. Most ghrelin receptors in nonmammalian species have been identified in fish (20 species). In other species, they have been found in three species of amphibians, two species of reptilians, and five species of aves. For further details, we would like to refer to our recent review (Kaiya et al. 2013a).

When comparing the primary structure of the ghrelin receptor protein in nonmammals, we find two interesting features. One is the presence of orthologous isoforms with different structural properties, i.e., GHS-Ra and GHS-R1alike receptor (GHS-R1a-LR). The other is the isoforms that may have occurred through whole-genome duplication (WGD) or polyploidization limited to teleost fish.

GHS-Ra, meaning the GHS-R type-a, is the umbrella term for two ghrelin receptor isoforms: GHS-R1a and GHS-R2a. These two receptor isoforms are considered to be derived by a WGD event. A limited numbers of teleost fishes such as Cypriniformes (e.g., goldfish, carp, and zebrafish) and Siluriformes (e.g., channel catfish) have GHS-R1a and 2a. The AA sequences of GHS-R2a share $\sim 70 \%$ identity with those of GHS-R1a (Small et al. 2009, Kaiya et al. 2010). The two isoforms are encoded by separate genes, e.g., the zebrafish GHS-R1a and GHS-R2a genes are located separately on chromosomes 4 and 24 respectively. This is in contrast to tetrapods including mammals, birds, reptiles, and amphibians, which have the GHS-R1a only.

Another orthologous isoform of the ghrelin receptor is GHS-R1a-LR. We designated this when discovered the receptor in Mozambique tilapia and rainbow trout (Kaiya et al. 2009a,b). GHS-R1a-LRs have unique features. One is that the second extracellular loop (ECL2) that connects TMDs 4 and 5 is notably longer when compared with that of the GHS-Ra (for a review, see Kaiya et al. (2013a)).

Published by Bioscientifica Ltd 
Another is that an intracellular $\mathrm{Ca}^{2+}$ increase in response to ghrelin or GHSs is not confirmed in GHS-R1a-LR (Kaiya et al. 2009a,b), although pharmacological doses could increase intracellular $\mathrm{Ca}^{2+}$ of mammalian cells expressing GHS-R1a-LR in pufferfish and black porgy (Palyha et al. 2000, Chan \& Cheng 2004). This dissimilarity between the GHS-Ra and GHS-R1a-LR is also evident in the phylogenetic relationship based on their AA sequences (Fig. 3). We can see that only a limited number of fish classified as Percomorpha within the superorder Acanthopterygii have GHS-R1a-LR, i.e., Perciformes such as black porgy (Acanthopagrus schlegelii) and tilapia (Oreochromis mossambicus); Gasterosteiformes such as stickleback (Gasterosteus aculeatus) and medaka (Oryzias latipes); Tetraodontiformes such as pufferfishes (Spheroides nephelus, Tetraodon nigroviridis, and Takifugu rubripes); and Salmoniformes such as rainbow trout (Oncorhynchus mykiss). The common denominators among these are that they are the most evolutionally advanced groups of teleost fishes.
Furthermore, there is an isoform that may have occurred by polyploidization in the GHS-Ra and GHSR1a-LR. This has been found in a few species of teleost fish and shows much higher identity (95\%) when compared with the identity $(70 \%)$ of isoforms occurred by genome duplication such as GHS-Ra. A representative species that has the isoform is goldfish. Goldfish has two ghrelin receptor isoforms that occurred by genome duplication: GHS-R1a and GHS-R2a. In addition to these, each receptor has the isoforms that may be occur through polyploidization, namely GHS-R1a-1 and 1a-2, and GHS-R2a-1 and 2a-2. Each receptor originates from a separate gene (Kaiya et al. 2010). This type of isoform is also found in GHS-R1a-LR of the rainbow trout i.e., the DQTA/LN-type and ERAT/IS-type GHS-R1a-LR (Kaiya et al. 2009b). The names of these isoforms indicate AA substitutions at D20E Q32R T54A A62T L168I and N264S (denoted as AA followed by AA position). It has been demonstrated that these two AA sequences are derived from at least three

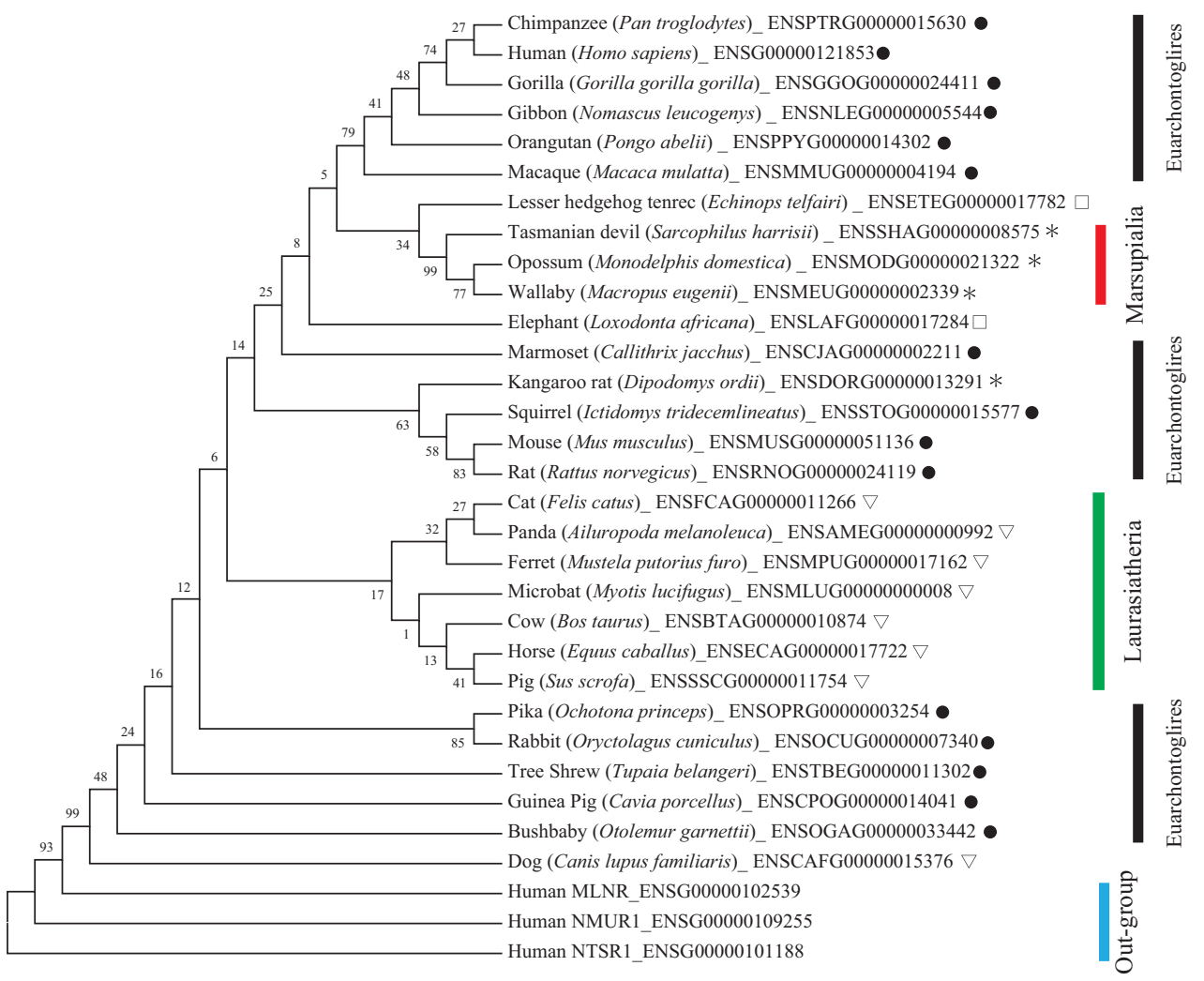

\section{Figure 2}

Molecular phylogenetic tree of the ghrelin receptor (GHS-R1a) in mammals. The phylogenetic tree of amino acid (AA) sequences was constructed by using the neighbor-joining (NJ) method with MEGA4 Software (http://www.megasoftware.net/). The numbers on the branch points are the bootstrap values (as percentages based on 1000 replicates). AA sequences obtained from the Ensembl Genome Browser (http://www.ensembl.org/index.html). GenelD shows the following species name. Receptors for human motilin (MLNR), neuromedin-U (NMUR1), and neurotensin (NTSR1) were used as the out group. Symbols are defined as follows: closed circle, Euarchontoglires; open square, Afrotheria; asterisk, Marsupialia; open down triangle, Laurasiatheria. http://jme.endocrinology-journals.org DOI: 10.1530/JME-13-0175
๑ 2014 Society for Endocrinology Printed in Great Britain
Published by Bioscientifica Ltd 
distinct genes: the ERAT/IS-type originates from one gene and the DQTA/LN-type derives from two separate genes (Kaiya et al. 2009b). Thus the constitutions of the ghrelin receptors in nonmammalian vertebrates are more complicated than their mammalian counterparts.

\section{Multiplicity of nonmammalian ghrelin receptors}

The multiplicity of nonmammalian ghrelin receptors in a limited number of fish is the result of genome polyploidization, in which there are two patterns. One is the substitution of $\sim 30 \%$ of the AA sequence, as seen in the GHS-R1a and GHS-R2a isoforms in goldfish, zebrafish, and channel catfish (Olsson et al. 2008, Small et al. 2009, Kaiya et al. 2010). We currently believe that this pattern originates from a chromosomal duplication after 3R-WGD (Meyer \& Schartl 1999, Jaillon et al. 2004). The other pattern is the substitution of only $5 \%$ of the AA sequence, as seen between goldfish GHS-R1a-1 and 1a-2, between goldfish GHS-R2a-1 and 2a-2, and between rainbow trout GHS-R1aLRs. We speculate that this pattern is derived by genetic recombination after a frame-shift mutation that occurred in the paternal or maternal allele. As an exception, however, polyploidization of the ghrelin receptor does not seem to have occurred in Perciformes such as tilapia, although tilapia experienced 3R-WGD (Kaiya et al. 2009b). Current data are too scarce to provide a conclusive explanation for the lack of polypoidization in this species.

\section{Distribution of the ghrelin receptors and the difference between mammals and nonmammalian vertebrates}

In mammals, the distribution of the ghrelin receptor is most extensively studied in laboratory mammals. Although a widespread distribution of the ghrelin receptor has been demonstrated, the highest levels of expression (ghrelin receptor mRNA) has been detected in the pituitary gland (Gnanapavan et al. 2002, Ueberberg et al. 2009), which is consistent with the role of ghrelin in the regulation of GH release. In general, the ghrelin receptor transcripts have also been detected in brain areas linked to energy homeostasis such as the hypothalamus, hippocampus, substantia nigra, ventral tegmental area, and dorsal and median raphe nuclei (Bennett et al. 1997, Guan et al. 1997, Kageyama et al. 2005, Zigman et al. 2006, Chen et al. 2009), although clear species differences in the distribution, e.g., between lemurs and rats, have been reported (Mitchell et al. 2001). The ghrelin receptor mRNA is also detected in various peripheral tissues such as the thyroid, heart, lung, liver, kidney, pancreas, stomach, spleen, intestine, adrenal gland, testis, and adipose tissue (Gnanapavan et al. 2002, Barreiro et al. 2003, Dass et al. 2003, Kageyama et al. 2005, Camiña 2006, Sun et al. 2007, Kitazawa et al. 2011).

The GHS-R1b splice variant of the ghrelin gene shows a different pattern of expression when compared with that of the GHS-R1a. The highest expression was found in the skin, followed by the myocardium, pituitary, thyroid gland, and pancreas of humans (Gnanapavan et al. 2002). It has been suggested that GHS-R1b plays a role for the trafficking of the GHS-R1a to the cell surface (Leung et al. 2007), but this widespread and different/graded levels of expression among tissues suggest an unknown physiological relevance of GHS-R1b in each tissue.

What about the tissue distribution of the ghrelin receptor in nonmammalian vertebrates? Similar to mammals, the GHS-R1a or GHS-R1a-LR transcripts have been found in various brain regions and peripheral organs, and the pituitary is the predominant expressing site for the ghrelin receptor isoforms in the majority of species, e.g. the channel catfish (Small et al. 2009), chickens (Geelissen et al. 2003, Tanaka et al. 2003, Saito et al. 2005, Richards et al. 2006, Yamamoto et al. 2008), and ducks (Nie et al. 2009) for GHS-R1a, and in the black porgy (Chan \& Cheng 2004), orange-spotted grouper (Chen et al. 2008), and rainbow trout (Kaiya et al. 2009b) for GHS-R1a-LR. An exception is frogs, where GHS-R1a mRNA is not detected in the pituitary but mainly in the brain (Kaiya et al. 2011a). Thus, ghrelin receptor expression in the pituitary gland is not a dominant feature in all nonmammalian species.

The brain is the tissue showing the second highest expression of the ghrelin receptor in fish and birds. In addition, the ghrelin receptor gene expression has also been detected in various amounts in more or less all peripheral tissues, such as the eyes, heart, thymus, liver, stomach, intestine, spleen, gill, gall bladder, muscle, kidney, head kidney, Brockmann bodies, skin, muscle, and gonads for fish (Chan \& Cheng 2004, Chen et al. 2008, Kaiya et al. 2009a,b, Small et al. 2009, Cruz et al. 2010), the stomach and gonads, and to a lesser extent in the small and large intestines, adrenal gland, and kidney in frogs (Kaiya et al. 2011a), and the heart, lung, thymus, liver, spleen, pancreas, gastrointestinal tract, adrenal gland, kidney, gonads, breast muscle, subcutaneous fat, leg muscle, abdominal fat, and uropygial gland in birds (Geelissen et al. 2003, Tanaka et al. 2003, Saito et al. 2005, Richards et al. 2006, Kitazawa et al. 2009, Nie et al. 2009). In birds, strain differences (Geelissen et al. 2003, Tanaka

Published by Bioscientifica Ltd 
et al. 2003, Richards \& McMurtry 2010) and a regionspecific expression in the gastrointestinal tract (Kitazawa et al. 2009) have been reported. In summary, these data indicate that ghrelin acts on various organs in nonmammalian vertebrates as it does in mammals.

Cypriniformes fish such as goldfish and zebrafish, as well as Siluriformes such as channel catfish, have paralogous GHS-Ra, GHS-R1a and $2 a$, showing different expression levels and tissue patterns (Small et al. 2009, Cruz et al. 2010, Kaiya et al. 2010). This suggests different mechanisms underlying the regulation of the expression of these genes.

The presence of GHS-R1b or an expected receptor, $G H S-R 1 b-L R$, in nonmammalian vertebrates has been reported: the GHS-R1b-LR mRNA has been detected in various brain regions of the black porgy whereas only a low expression was measured in peripheral tissues (Chan \& Cheng 2004). In rainbow trout and channel catfish, GHS-R1b mRNA is strongly expressed in the pituitary, whereas a weak expression is observed in other peripheral organs (Kaiya et al. 2009b, Small et al. 2009). This is different from the results reported for mammals (Gnanapavan et al. 2002). On the other hand, in Mozambique tilapia, ghrelin receptor transcripts are detected in the stomach, adipose tissue, gill, liver, intestine, spleen, kidney, and muscle as well as in the brain (Kaiya et al. 2009a). Likewise, in orange-spotted grouper, the $G H S-R 1 b$ mRNA is detected in various peripheral organs as well as in the brain and pituitary (Chen et al. 2008).

In birds, there is a splice variant which is different from GHS-R1b in structure, namely the GHS-R1aV. The gene of this variant is expressed in almost all tissues of chickens, and the expression pattern is almost identical to that of GHS-R1a (Geelissen et al. 2003, Tanaka et al. 2003, Richards $\&$ McMurtry 2010). Other splice variants, the GHS-Rtv and GHS-Rtv-like receptor, show a limited and specific expression in the ovary of chickens (Sirotkin et al. 2006) and in the proventriculus and gizzard of the Japanese quail (Kitazawa et al. 2009) respectively. For further information about the structure of these receptor variants in birds, we would like to refer to a detailed review (Kaiya et al. 2013a).

\section{Evolution of ghrelin receptors in vertebrates with focus on nonmammalian vertebrates}

We prepared a phylogenetic tree for the ghrelin receptors identified so far, and we will use it in this study to speculate about the evolution of the ghrelin receptor in vertebrates including both mammals and nonmammals (Figs. 3 and 4).
In a search of the Ensemble database (http://www. ensembl.org/Petromyzon_marinus/Info/Index/), a partial AA sequence with $50 \%$ identity to human GHS-R1a was detected in sea lamprey (Petromyzon marinus), which belongs to the group Cyclostomata in the class Agnatha, a class of fish with the characteristics of ancient basal vertebrates. This receptor could not be placed in any branch of GHS-Ra or GHS-R1a-LR when the phylogenetic analysis was carried out (Fig. 3). Therefore, the receptor of the sea lamprey may have the ancestral characteristics of the ghrelin receptor.

Gnathostomes are divided into Chondrichthyes and Osteichthyes (Fig. 4). In Chondrichthyes, genomedecoding efforts have focused on the elephant shark (Callorhinchus milii; http://esharkgenome.imcb.a-star. edu.sg). In a search of the database, we found a partial receptor sequence similar to human GHS-R1a with 51\% identity. The characteristics of the elephant shark receptor are similar to those of GHS-Ra rather than the GHS-R1aLR. Osteichthyes have split into Actinopterygii (the rayfinned fish lineage) and Sarcopterygii (the lobe-finned fish lineage) during evolution (Fig. 4). Sarcopterygii includes coelacanths, the family of fish that led to tetrapods. In a search of the Ensembl database for coelacanths (http:// www.ensembl.org/Latimeria_chalumnae/Info/Index/), a receptor sequence that has similar characteristics to GHS-R1a was found. This is in line with the presence of the GHS-R1a in all tetrapods. On the other hand, in Actinopterygii, two types of the ghrelin receptor, GHS-Ra and GHS-R1a-LR are present. Actinopterygii where the ghrelin receptor has been identified comprised four classes of fish: Perciformes, Salmoniformes, Cypriniformes, and Siluriformes (Fig. 4). Perciformes and Salmoniformes have the GHS-R1a-LR, and Cypriniformes and Siluriformes have the GHS-Ra. Furthermore, Salmoniformes and Cypriniformes have paralogous isoforms that occurred through polyploidization. Why do Actinopterygian fish have two types of the ghrelin receptor? What is the difference from other group? One answer may lie in a common characteristic that we noticed in species with the GHS-Ra: they have swim bladders that have evolved from lungs as outlined below.

Primitive Teleostei had lungs, and these evolved into swim bladders in some Teleostei (Farmer 1997, Zaccone et al. 2012). In Polypteriformes, Semionotiformes, and Amiiformes, which are primitive Actinopterigii, and lungfish, which belong to Sarcopterygii, swim bladders perform pulmonary respiration separately from gill breathing and so they function as the lungs. In contrast, Acipenseriformes and Teleostei have complete swim

Published by Bioscientifica Ltd 

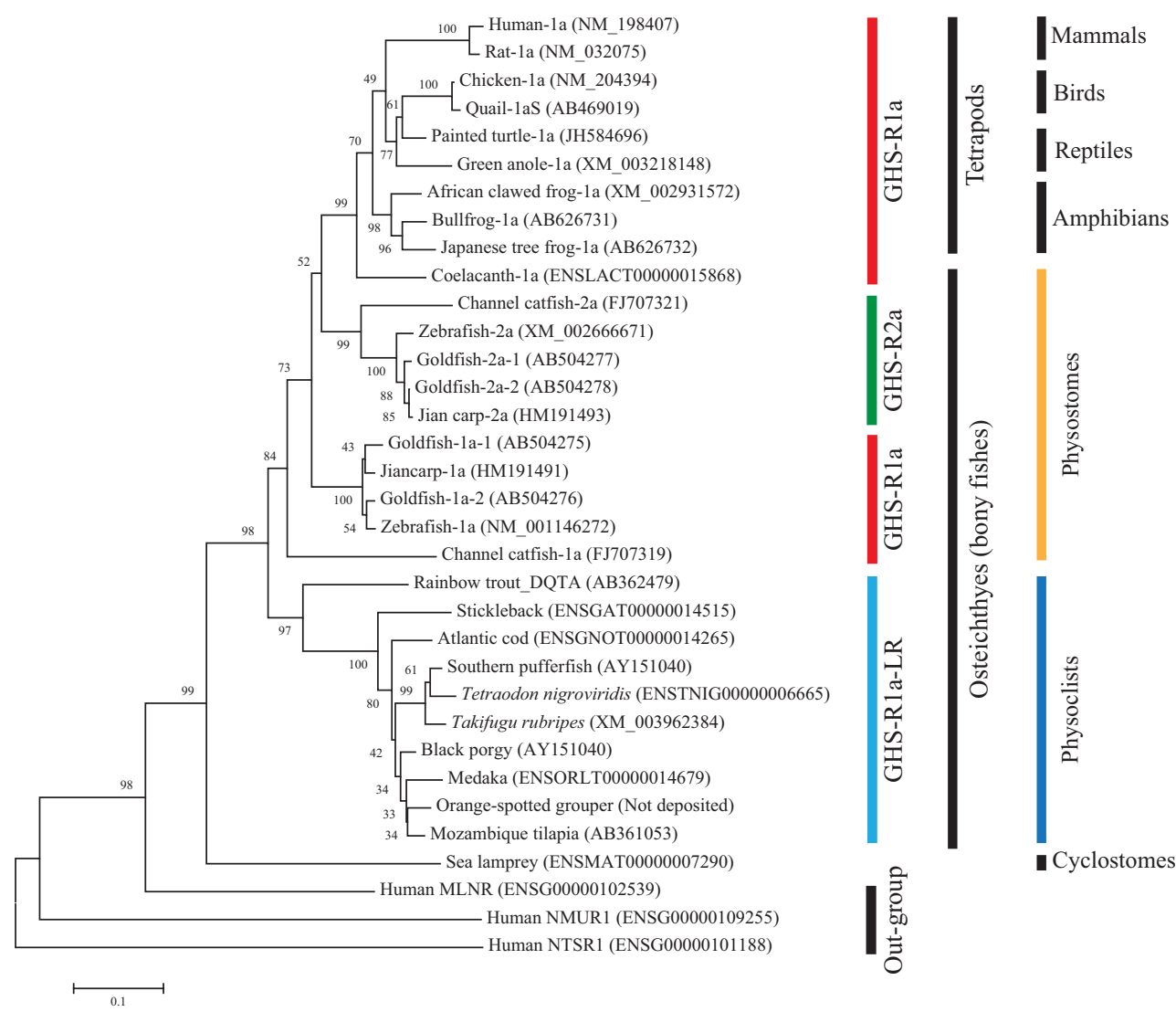

\section{Figure 3}

Molecular phylogenetic tree of GHS-Ra and GHS-R1a-LR in nonmammalian vertebrates. The phylogenetic tree of amino acid (AA) sequences was constructed by using the neighbor-joining (NJ) method with MEGA4 (http://www.megasoftware.net/). The numbers on the branch points are the bootstrap values (as percentages based on 1000 replicates). The scale bar indicates the average number of substitutions per position (a relative

bladders, which have lost the breathing function. Species with the GHS-R1a-LR share a morphological characteristic: i.e., the lack of a connection between the swim bladder and the alimentary canal. Such fish are called 'physoclistous' fish, and Perciformes and Salmoniformes are included. In contrast, Cypriniformes and Siluriformes, which have the GHS-Ra, have a pneumatic duct connecting the swim bladder to the alimentary canal. These fish are called 'physostomous' fish. Therefore, teleosts that have swim bladders derived from lungs and tetrapods, which have lungs, have the GHS-Ra isoform. For some reason, in 'physoclistous' fish that have developed complete swim bladders during the evolutional process, structures of the GHS-Ra have changed leading to the ghrelin receptor GHS-R1a-LR. We speculate that a reason that different forms of the ghrelin receptor are present in the ray-finned fish lineage (Actinopterygii), but not the Printed in Great Britain measure of evolutionary distance). AA sequences obtained from the NCBI BLAST (http://blast.ncbi.nlm.nih.gov/Blast.cgi) or the Ensembl Genome Browser (http://www.ensembl.org/index.html). Accession number of the gene or GenelD shows the following species name. Receptors for human motilin (MLNR), neuromedin-U (NMUR1), and neurotensin (NTSR1) were used as the out group.

lobe-finned fish (Sarcopterygii), might be an involvement of the third round of 3R-WGD that occurred only in Actinopterygii lineage (Meyer \& Schartl 1999, Jaillon et al. 2004). A complication is that highly similar receptor isoforms are present in goldfish (e.g., GHS-R1a-1 and 1a-2) or rainbow trout (DQTA-type and ERAT-type) (Kaiya et al. 2009b, 2010). It may be hypothesized that their polyploidization event that occurred after 3R-WGD (Leggatt \& Iwama 2003), and a tandem duplication of the genes, as occurred in the opsin gene in these species (Rennison et al. 2012) may be responsible for these new traits. Among Euteleosts, it is speculated that the presence of multiple paralogoue isoforms may be a peculiar characteristic for Ostariophysi and Protacanthopterygii (Meyer \& Schartl 1999, Jaillon et al. 2004), and further studies are necessary to clarify this issue on the ghrelin receptor.

Published by Bioscientifica Ltd 


\section{Comparison of the ghrelin receptor signaling}

Current knowledge shows that the intracellular signaling triggered by the ghrelin receptor follows the general pattern that the ghrelin receptor activates a G-protein subtype, $\mathrm{G} \alpha_{\mathrm{q} / 11}$, which induces the production of inositol triphosphate (IP3), which releases $\mathrm{Ca}^{2+}$ from intracellular calcium stores, whereas diacylglycerol activates protein kinase C (PKC) (Howard et al. 1996, Wettschureck et al. 2005). These events are not only seen in cells transfected with GHS-R1a but also in pituitary somatotrophs (Cheng et al. 1991, Herrington \& Hille 1994, Lei et al. 1995, Bresson-Bépoldin \& Dufy-Barbe 1996, Lania et al. 1998). In neuropeptide Y-containing neurons, ghrelin-induced $\mathrm{Ca}^{2+}$ increase is responsible for the calcium influx through $\mathrm{N}$-type calcium channels via the cAMP- protein kinase A (PKA) signaling pathway through a G-protein coupled to the ghrelin receptor (Kohno et al. 2003). In porcine somatotropes, the three distinct second messenger systems, such as adenylyl cyclase/PKA, phospholipase C (PLC)/PKC, and extracellular $\mathrm{Ca}^{2+}$ systems, are sequentially involved in the ghrelin response (Malagón et al. 2003).

On the other hand, according to the review paper of Camiña (2006), ghrelin activates MAPK through mediating the Ras-Raf-MEK-MAPK pathway through activation of a tyrosine kinase receptor in adrenal cells. In addition, another mechanism through which ghrelin may activate MAPK is via PI3 kinase and PLC through $\mathrm{G}_{\mathrm{i} / \mathrm{o}}$ as shown in 3T3-L1 cells. Furthermore, in hepatoma cells, ghrelin has been shown to increase MAPK activity via the association of growth factor receptor-bound protein 2 with insulin receptor substrate-1 and PI3 kinase. These three MAPK pathways are associated with stimulation of cell proliferation. On the other hand, ghrelin exerts an inhibitory effect on angiogenic factors such as fibroblast growth factor-2 (Conconi et al. 2004).

Interestingly, the GHS-R1a shows a constitutive activity (high-basal IP3 production) in the absence of agonists (Herrington \& Hille 1994, Lania et al. 1998, Holst et al. 2005). This activity causes a PLC-PKC-dependent $\mathrm{Ca}^{2+}$ mobilization that is associated with the L-type voltage-gated calcium channel. The basal PLC as well as the extracellular signal-regulated kinase 1 and 2 activity is activated or inhibited by GHRP-6 and a GHS-R antagonist, [D-Lys3]-GHRP-6 respectively (Chu et al. 2007).

Nonmammalian ghrelin receptors have been successfully expressed in mammalian cells, and these show a rise in intracellular $\mathrm{Ca}^{2+}$ upon stimulation with ghrelin or GHSs (Palyha et al. 2000, Chan \& Cheng 2004, Chan et al. 2004, Kitazawa et al. 2009, Kaiya et al. 2010, 2011a,
Tachibana et al. 2011). A similar $\mathrm{Ca}^{2+}$ mobilization was also observed in goldfish somatotrophs and gonadotrophs in the pituitary (Grey \& Chang 2009, 2013, Grey et al. 2010), which are responsible for the release of GH and luteinizing hormone (LH) respectively. The signaling pathways have been gradually clarified: the ghrelininduced GH and LH release from goldfish pituitary cells are regulated by nitric oxide signaling (Grey \& Chang 2013), and PKA and PKC differently regulate it (Grey \& Chang 2011). On the other hand, in fish-specific GHSR1a-LRs expressing cells found in the pufferfish and black porgy (Palyha et al. 2000, Chan \& Cheng 2004), $\mathrm{Ca}^{2+}$ signaling is activated by GHSs, but relatively high doses of receptor agonists are required when the dose was compared with that required to stimulate the GHS-Ra. In addition, no $\mathrm{Ca}^{2+}$ signaling could be detected in GHS-R1a-LRs expressing cells of tilapia and rainbow trout, even though when homologous ghrelin was used (Kaiya et al. 2009a,b). As described earlier, these receptors have a specific structural feature such as the long ECL2 (Kaiya et al. 2013a). Further studies are needed to elucidate the relationship between ghrelin signaling mechanisms and receptor structures involved in the expression of the activity.

\section{Ghrelin receptor evolution, ligand selectivity, and receptor functionality to ghrelin}

The evolution of a new endocrine function occurs with the acquisition of a new physiological function and the establishment of a new ligand-receptor system controlling this function. In general, because a hormone does not have any bioactivity itself without binding to its receptor, if the hormone evolves but a receptor does not evolve to bind the hormone, no new functionality will arise. This theory predicts that coevolution of the ligand and its receptor needs to occur to produce new functionality and raises the question whether coevolution has occurred in the case of ghrelin and the ghrelin receptor.

During the long history of ghrelin receptor evolution, the part of the receptor that is least likely to change is the structure that participates in the ligand binding. Both nonmammalian and mammalian ghrelin receptors are capable of binding synthetic GHSs such as GHRP2, GHRP6, ipamorelin, L163,255, L692,585, L163,540, and hexarelin (for a review, see Kaiya et al. (2008, 2011b)). Interestingly, the degree of agonistic activity of each artificial GHS varies according to the receptor isoform present in the animal, indicating that the structural interactions between the ligand and receptor that are essential for receptor activation did not change during the evolution of vertebrates.

Published by Bioscientifica Ltd 
Feighner et al. (1998) reported on the relationship between certain AA residues and agonist binding to human GHS-R1a. The AA residues D99, C116, E124, M213, S217, and H280, have crucial roles in receptor activation. In particular, M213, S217, and H280 are required for the binding of GHRP6 and L692,585. The above six AA residues are conserved in GHS-Ra or GHSR1a-LR identified in all nonmammalian vertebrates except stickleback (Kaiya et al. 2013a). This suggests that both the GHS-Ra and GHS-R1a-LR in nonmammalian vertebrates have the ability to bind GHRP6. However, GHS-R1a-1, GHS-R1a-2, and GHS-R2a-2 in goldfish selectively bind GHRP6 or hexarelin (Kaiya et al. 2010, 2013a), and GHS-R1a-LRs from rainbow trout and tilapia do not show $\mathrm{Ca}^{2+}$ response to GHRP6 in transfected HEK293 or
CHO cells at all (Kaiya et al. 2009a,b). Thus, the interaction between the agonist and key AA residues in the receptor related to agonist binding may be more complicated than anticipated by Feighner et al. (1998). The minimum essential structure of ghrelin for binding to the receptor is the first four AAs (GSSF) including the acyl modification (Bednarek et al. 2000, Matsumoto et al. 2001).

As mentioned earlier, ghrelin receptor shows strong, ligand-independent constitutive signaling in transfected COS7 or HEK293 cells in addition to ligand-dependent $\mathrm{Ca}^{2+}$ signaling (Holst et al. 2003). In the case of human GHS-R1a, it has been reported that V160, F279, A204, I134, and A204 are important AA residues for the constitutive receptor activity, i.e., distinct sets of AAs are involved in ligand binding and constitutive activity (Holst

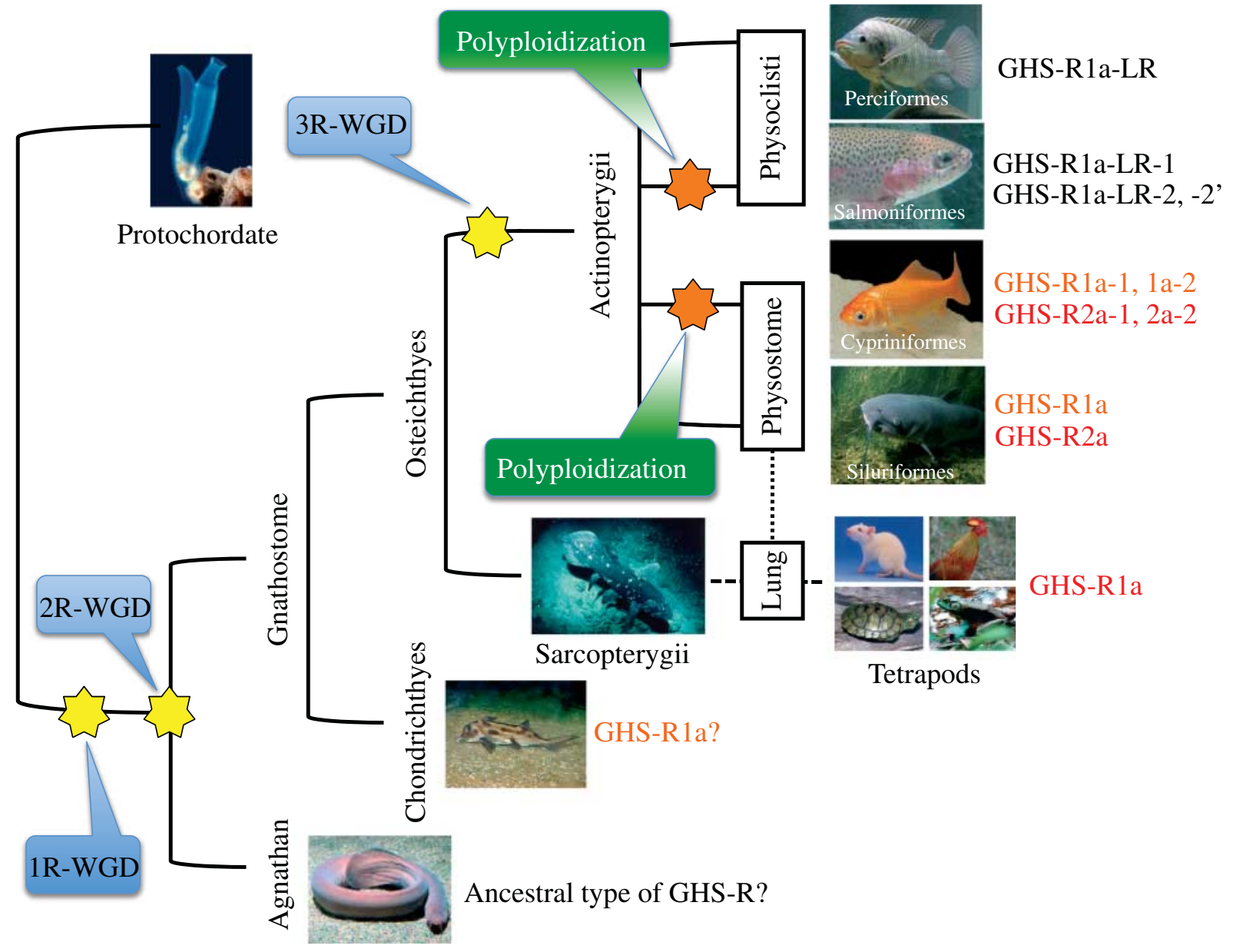

Figure 4

Schematic diagram of the evolution of the ghrelin receptor in vertebrates. The scheme includes data for Cyclostomata (Agnathans) and elephant shark (Chondrichthyes). The question marks indicate the possibility that an amino acid fragment of their receptor is GHS-R1a or an ancestral type of GHS-R. The three whole-genome duplication (WGD) events are shown by yellow stars. Polyploidization that occurred in some teleost species of
Actinopterygii is shown by orange stars. The GHS-Ra and its isoforms are found in physostomous fish, which have the anlage of lungs, and tetrapods, which have lungs. In contrast, the GHS-R1a-LR and its isoforms are found in physoclistious fish, which have swim bladders that are not connected to the alimentary tract. http://jme.endocrinology-journals.org DOI: 10.1530/JME-13-0175
(C) 2014 Society for Endocrinology Printed in Great Britain
Published by Bioscientifica Ltd 
et al. 2004, Liu et al. 2007, Rediger et al. 2011). Because these AA residues do not substitute and are conserved in the GHS-Ra and GHS-R1a-LR isoforms identified in nonmammalian vertebrates (Kaiya et al. 2013a), it is presumed that constitutive activity has been conserved in the evolution of the ghrelin receptor, although the only nonmammalian species where this has been confirmed is in the receptor for the black porgy (Leung et al. 2007).

\section{Did ghrelin receptor and ghrelin peptide coevolve?}

In mammals, one form of ghrelin peptide and its receptor are present. However, as studies on nonmammalian vertebrates show that multiple forms of ghrelin and the ghrelin receptors exist, they have revealed that the evolution of the ghrelin receptor is more complicated
As described earlier, a plurality of the ghrelin receptors has been found, although only in a limited number of teleost lineages such as Salmoniformes, Cypriniformes, and Siluriformes, in which polyploidization of the genome has occurred. The multiplicity results in two patterns of genome polyploidization, as described earlier: chromosomal duplication by 3R-WGD and the genetic recombination after a frame-shift mutation that may occur in the paternal or maternal allele.

Now, the question then arises whether ghrelin, the ligand for the receptor, also duplicated or if an increased number of isoforms is associated with multiplicity of the receptor. Consequently, there is no evidence for multiple ghrelin genes, which means a multiple number of the ghrelin sequence, in any species (Fig. 5; Kaiya et al. 2011b). This suggests that the evolution of the ghrelin receptor and its ligand, ghrelin, occurred independently, and that evolutionary pressures were applied to the receptor gene only. Consequently it may be speculated that a coevolution

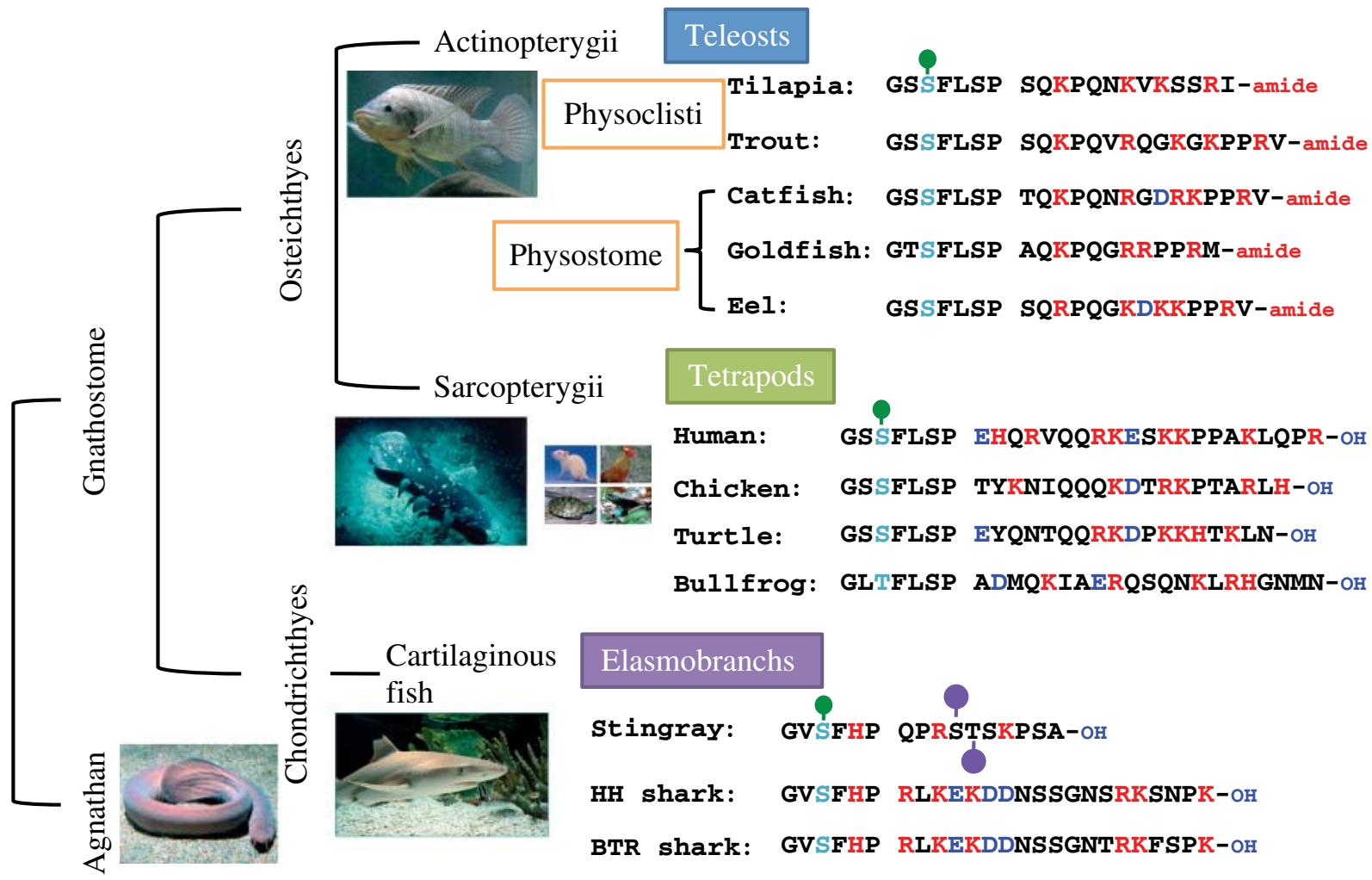

Figure 5

Schematic diagram of the evolution of ghrelin. In elasmobranchs, $\mathrm{HH}$ shark, and BTR shark denote hammerhead shark and blacktip reef shark respectively. In each ghrelin amino acid (AA) sequence, light blue letters indicate AAs that have fatty acid modifications, and red or blue letters indicate AAs that have a positive or negative charge respectively. The carboxyl terminus of ghrelin in teleosts is amidated. Fatty acid modification is also indicated with a green symbol on the first sequence in each group.
(C) 2014 Society for Endocrinology Printed in Great Britain
In elasmobranchs, in addition to the acyl modification, ghrelin-like peptide of stingray has an additional modification by mucin-type carbohydrate chains, as shown in the purple symbols (Kaiya et al. 2009c). Some ghrelin molecules have truncated C-termini due to the post-translational processing. However, the presence of isoforms with AA substitutions has not been identified, even in fish species where polyploidization of the ghrelin receptor is seen. 
of the ghrelin receptor and ghrelin has not occurred. Interestingly, some evidence suggests that multiplicity (evolution) of the ghrelin receptor may accompany the change in ligand selectivity, as outlined below.

In ghrelin receptors for goldfish (Kaiya et al. 2010), GHSR2a does not show any ligand selectivity between goldfish ghrelin and GHSs such as GHRP-6 and hexarelin. In contrast, GHS-R1a shows ligand selectivity for activation of the receptor; GHRP- 6 does not elicit an increase in intracellular $\mathrm{Ca}^{2+}$ through GHS-R1a. This finding suggests that the numerous differences in constructing AA residues between GHS-R1a and GHS-R2a affect GHRP-6 selectivity, even though the key AAs for GHRP-6 binding to GHS-R1a have not been changed during receptor evolution, as mentioned earlier (Feighner et al. 1998). The reason why goldfish GHS-R1a shows ligand selectivity can be speculated on as follows. In the phylogenetic tree analysis (Fig. 3), GHSR2a, but not GHS-R1a, for Cyprinoformes and Siliuriformes were classified in the same clade as tetrapod GHS-R1a. We believe that this may be because of the historical naming of these receptors. The zebrafish GHS-R1a was the first GHS-Ra isoform identified in fish species (Olsson et al. 2008). Thereafter, our group discovered the existence of a receptor isoform for GHS-R1a in zebrafish in a search of the NCBI database and designated it GHS-R2a (for a review, see Kaiya et al. (2008)). Therefore, primarily GHS-R2a of Teleostei has the same feature as tetrapod GHS-R1a, which does not show ligand selectivity, and rather retains the basic features of the ghrelin receptor. In contrast, the current GHS-R1a of Teleostei may be an 'evolved' type of the ghrelin receptor and show ligand selectivity. Furthermore, evolutionally advanced fishes do not have GHS-Ra but have GHS-R1a-LR, although receptor activation and ligand-binding capacity have not been confirmed in some fish species after ghrelin treatment (Kaiya et al. 2009a,b). Thus, it can be speculated that the ghrelin receptor may be in the middle of evolving independently from ghrelin (Fig. 4).

\section{Conclusion}

In this review, we have discussed the evolution of the ghrelin receptor in vertebrates and shown that differences in the structure and function of the ghrelin receptor in various vertebrate species may relate to the formation of lungs, a physoclistous swim bladder, or a physostomous swim bladder. The physostome, which has a pneumatic duct connecting the swim bladder to the alimentary canal, is a vestigial character derived from ancestral fish that had lungs. Thus, the presence of GHS-Ra in physostomous fish and tetrapods, but not physoclistous fish, suggests that
GHS-Ra is a rather old type of the ghrelin receptor. In contrast, another type of GHS-Ra, the GHS-R1a-LRs, for which we could not confirm a functional activity using a mammalian cell expression system, is present only in a limited number of teleosts. These are the evolutionally advanced species in terms of both morphology and function, being physoclistous fish. Thus, GHS-R1a-LR should be a more recently developed type of ghrelin receptor. However, the relationship between the function and evolution of lungs, and ghrelin's function is unknown. Further studies are necessary to clarify the physiological relevance of the multiplicity of the ghrelin receptor in some teleost species, and the possibility of the presence of another ligand, which means a ghrelin isoform or unknown peptide, for the multiple ghrelin receptors. Such knowledge would give us a deeper understanding of the significance of the ghrelin-ghrelin receptor system in vertebrates.

\section{Declaration of interest}

The authors declare that there is no conflict of interest that could be perceived as prejudicing the impartiality of the review.

\section{Funding}

H K, M M, and K K were supported by a Grant-in-Aid for Scientific Research from the Ministry of Education, Culture, Science, Sports, and Technology (MEXT, KAKENHI) of Japan and by the Takeda Science Foundation.

\section{Acknowledgements}

The authors' express their sincere thank to Dr Elisabeth Jönsson Bergman, University of Gothenburg, Department of Biological and Environmental Sciences for critical reading and giving us valuable comments on this manuscript. They also thank Mrs Azumi Ooyama for excellent technical assistance.

\section{References}

Asakawa A, Inui A, Fujimiya M, Sakamaki R, Shinfuku N, Ueta Y, Meguid MM \& Kasuga M 2005 Stomach regulates energy balance via acylated ghrelin and desacyl ghrelin. Gut 54 18-24. (doi:10.1136/gut. 2004.038737)

Barreiro ML, Suominen JS, Gaytán F, Pinilla L, Chopin LK, Casanueva FF, Diéguez C, Aguilar E, Toppari J \& Tena-Sempere M 2003 Developmental, stage-specific, and hormonally regulated expression of growth hormone secretagogue receptor messenger RNA in rat testis. Biology of Reproduction 68 1631-1640. (doi:10.1095/biolreprod.102.008862)

Bednarek MA, Feighner SD, Pong SS, McKee KK, Hreniuk DL, Silva MV, Warren VA, Howard AD, Van Der Ploeg LH \& Heck JV 2000 Structure-function studies on the new growth hormone-releasing peptide, ghrelin: minimal sequence of ghrelin necessary for activation of growth hormone secretagogue receptor 1a. Journal of Medicinal Chemistry 43 4370-4376. (doi:10.1021/jm0001727)

Bennett PA, Thomas GB, Howard AD, Feighner SD, van der Ploeg LH, Smith RG \& Robinson IC 1997 Hypothalamic growth hormone secretagogue-receptor (GHS-R) expression is regulated by growth 
hormone in the rat. Endocrinology 138 4552-4557. (doi:10.1210/en. 138.11.4552)

Bresson-Bépoldin L \& Dufy-Barbe L 1996 GHRP6-stimulated hormone secretion in somatotrophs: involvement of intracellular and extracellular calcium sources. Journal of Neuroendocrinology 8 309-314. (doi:10.1046/j.1365-2826.1996.04608.x)

Camiña JP 2006 Cell biology of the ghrelin receptor. Journal of Neuroendocrinology 18 65-76. (doi:10.1111/j.1365-2826.2005.01379.x)

Carlini VP, Perez MF, Salde E, Schiöth HB, Ramirez OA \& de Barioglio SR 2010 Ghrelin induced memory facilitation implicates nitric oxide synthase activation and decrease in the threshold to promote LTP in hippocampal dentate gyrus. Physiology \& Behavior 101 117-123. (doi:10.1016/j.physbeh.2010.04.026)

Chan CB \& Cheng CH 2004 Identification and functional characterization of two alternatively spliced growth hormone secretagogue receptor transcripts from the pituitary of black seabream, Acanthopagrus schlegeli. Molecular and Cellular Endocrinology 214 81-95. (doi:10.1016/j.mce. 2003.11.020)

Chan CB, Leung PK, Wise H \& Cheng CH 2004 Signal transduction mechanism of the seabream growth hormone secretagogue receptor. FEBS Letters 577 147-153. (doi:10.1016/j.febslet.2004.08.088)

Chen T, Tang Z, Yan A, Li W \& Lin H 2008 Molecular cloning and mRNA expression analysis of two GH secretagogue receptor transcripts in orange-spotted grouper (Epinephelus coioides). Journal of Endocrinology 199 253-265. (doi:10.1677/JOE-08-0325)

Chen CY, Asakawa A, Fujimiya M, Lee SD \& Inui A 2009 Ghrelin gene products and the regulation of food intake and gut motility. Pharmacological Reviews 61 430-481. (doi:10.1124/pr.109.001958)

Cheng K, Chan WW, Butler B, Barreto A Jr \& Smith RG 1991 Evidence for a role of protein kinase-C in His-D-Trp-Ala-Trp-D-Phe-Lys-NH2-induced growth hormone release from rat primary pituitary cells. Endocrinology 129 3337-3342. (doi:10.1210/endo-129-6-3337)

Chow KB, Sun J, Chu KM, Tai Cheung W, Cheng CH \& Wise H 2012 The truncated ghrelin receptor polypeptide (GHS-R1b) is localized in the endoplasmic reticulum where it forms heterodimers with ghrelin receptors (GHS-R1a) to attenuate their cell surface expression. Molecular and Cellular Endocrinology 348 247-254. (doi:10.1016/ j.mce.2011.08.034)

Chu KM, Chow KB, Leung PK, Lau PN, Chan CB, Cheng CH \& Wise H 2007 Over-expression of the truncated ghrelin receptor polypeptide attenuates the constitutive activation of phosphatidylinositol-specific phospholipase $\mathrm{C}$ by ghrelin receptors but has no effect on ghrelinstimulated extracellular signal-regulated kinase 1/2 activity. International Journal of Biochemistry \& Cell Biology 39 752-764. (doi:10.1016/ j.biocel.2006.11.007)

Civelli O 2012 Orphan GPCRs and neuromodulation. Neuron 76 12-21. (doi:10.1016/j.neuron.2012.09.009)

Civelli O, Saito Y, Wang Z, Nothacker HP \& Reinscheid RK 2006 Orphan GPCRs and their ligands. Pharmacology \& Therapeutics 110 525-532. (doi:10.1016/j.pharmthera.2005.10.001)

Conconi MT, Nico B, Guidolin D, Baiguera S, Spinazzi R, Rebuffat P, Malendowicz LK, Vacca A, Carraro G, Parnigotto PP et al. 2004 Ghrelin inhibits FGF-2-mediated angiogenesis in vitro and in vivo. Peptides 25 2179-2185. (doi:10.1016/j.peptides.2004.08.011)

Cruz SA, Tseng YC, Kaiya H \& Hwang PP 2010 Ghrelin affects carbohydrateglycogen metabolism via insulin inhibition and glucagon stimulation in the zebrafish (Danio rerio) brain. Comparative Biochemistry and Physiology - Part A, Molecular \& Integrative Physiology 156 190-200. (doi:10.1016/j.cbpa.2010.01.019)

Delhanty PJ \& van der Lely AJ 2013 Ghrelin: a new treatment for nonalcoholic fatty liver disease? Endocrine 43 247-248. (doi:10.1007/ s12020-012-9800-2)

Delhanty PJ, Neggers SJ \& van der Lely AJ 2012 Mechanisms in endocrinology: Ghrelin: the differences between acyl- and des-acyl ghrelin. European Journal of Endocrinology 167 601-608. (doi:10.1530/ EJE-12-0456)
Dass NB, Munonyara M, Bassil AK, Hervieu GJ, Osbourne S, Corcoran S, Morgan M \& Sanger GJ 2003 Growth hormone secretagogue receptors in rat and human gastrointestinal tract and the effects of ghrelin. Neuroscience 120 443-453. (doi:10.1016/S0306-4522(03)00327-0)

Diano S, Farr SA, Benoit SC, McNay EC, da Silva I, Horvath B, Gaskin FS, Nonaka N, Jaeger LB, Banks WA et al. 2006 Ghrelin controls hippocampal spine synapse density and memory performance. Nature Neuroscience 9 381-388. (doi:10.1038/nn1656)

Eizirik E, Murphy WJ \& O’Brien SJ 2001 Molecular dating and biogeography of the early placental mammal radiation. Journal of Heredity $\mathbf{9 2}$ 212-219. (doi:10.1093/jhered/92.2.212)

Farmer C 1997 Did lungs and the intracardiac shunt evolve to oxygenate the heart in vertebrates? Paleobiology 23 358-372. (doi:10.1666/00948373-23.3.358)

Feighner SD, Howard AD, Prendergast K, Palyha OC, Hreniuk DL, Nargund R, Underwood D, Tata JR, Dean DC, Tan CP et al. 1998 Structural requirements for the activation of the human growth hormone secretagogue receptor by peptide and nonpeptide secretagogues. Molecular Endocrinology 12 137-145. (doi:10.1210/me.12.1.137)

Fujimiya M, Ataka K, Asakawa A, Chen CY, Kato I \& Inui A 2012 Regulation of gastroduodenal motility: acyl ghrelin, des-acyl ghrelin and obestatin and hypothalamic peptides. Digestion 85 90-94. (doi:10.1159/ 000334654)

Geelissen SM, Beck IM, Darras VM, Kühn ER \& Van der Geyten S 2003 Distribution and regulation of chicken growth hormone secretagogue receptor isoforms. General and Comparative Endocrinology 134 167-174. (doi:10.1016/S0016-6480(03)00250-8)

Gnanapavan S, Kola B, Bustin SA, Morris DG, McGee P, Fairclough P, Bhattacharya S, Carpenter R, Grossman AB \& Korbonits M 2002 The tissue distribution of the mRNA of ghrelin and subtypes of its receptor, GHS-R, in humans. Journal of Clinical Endocrinology and Metabolism 87 2988-2991. (doi:10.1210/jc.87.6.2988)

Granata R, Baragli A, Settanni F, Scarlatti F \& Ghigo E 2010 Unraveling the role of the ghrelin gene peptides in the endocrine pancreas. Journal of Molecular Endocrinology 45 107-118. (doi:10.1677/JME-10-0019)

Grey CL \& Chang JP 2009 Ghrelin-induced growth hormone release from goldfish pituitary cells involves voltage-sensitive calcium channels. General and Comparative Endocrinology 160 148-157. (doi:10.1016/ j.ygcen.2008.11.006)

Grey CL \& Chang JP 2011 Differential involvement of protein kinase C and protein kinase A in ghrelin-induced growth hormone and gonadotrophin release from goldfish (Carassius auratus) pituitary cells. Journal of Neuroendocrinology 23 1273-1287. (doi:10.1111/j.1365-2826. 2011.02221.x)

Grey CL \& Chang JP 2013 Nitric oxide signaling in ghrelin-induced LH release from goldfish pituitary cells. General and Comparative Endocrinology 183 7-13. (doi:10.1016/j.ygcen.2012.11.022)

Grey CL, Grayfer L, Belosevic M \& Chang JP 2010 Ghrelin stimulation of gonadotropins (LH) release from goldfish pituitary cells: presence of the growth hormone secretagogue receptor (GHS-R1a) and involvement of voltage-sensitive $\mathrm{Ca}^{2+}$ channels. Molecular and Cellular Endocrinology 317 64-77. (doi:10.1016/j.mce.2009.12.024)

Großauer J, Kosol S, Schrank E \& Zangger K 2010 The peptide hormone ghrelin binds to membrane-mimetics via its octanoyl chain and an adjacent phenylalanine. Bioorganic \& Medicinal Chemistry 18 5483-5488. (doi:10.1016/j.bmc.2010.06.062)

Guan XM, Yu H, Palyha OC, McKee KK, Feighner SD, Sirinathsinghji DJ, Smith RG, Van der Ploeg LH \& Howard AD 1997 Distribution of mRNA encoding the growth hormone secretagogue receptor in brain and peripheral tissues. Brain Research and Molecular Brain Research 48 23-29. (doi:10.1016/S0169-328X(97)00071-5)

Gutierrez JA, Solenberg PJ, Perkins DR, Willency JA, Knierman MD, Jin Z, Witcher DR, Luo S, Onyia JE \& Hale JE 2008 Ghrelin octanoylation mediated by an orphan lipid transferase. PNAS 105 6320-6325. (doi:10.1073/pnas.0800708105) 
Herrington J \& Hille B 1994 Growth hormone-releasing hexapeptide elevates intracellular calcium in rat somatotropes by two mechanisms. Endocrinology 135 1100-1108. (doi:10.1210/endo.135.3.8070352)

Holst B, Cygankiewicz A, Jensen TH, Ankersen M \& Schwartz TW 2003 High constitutive signaling of the ghrelin receptor - identification of a potent inverse agonist. Molecular Endocrinology 17 2201-2210. (doi:10.1210/me.2003-0069)

Holst B, Holliday ND, Bach A, Elling CE, Cox HM \& Schwartz TW 2004 Common structural basis for constitutive activity of the ghrelin receptor family. Journal of Biological Chemistry 279 53806-53817. (doi:10.1074/jbc.M407676200)

Holst B, Brandt E, Bach A, Heding A \& Schwartz TW 2005 Nonpeptide and peptide growth hormone secretagogues act both as ghrelin receptor agonist and as positive or negative allosteric modulators of ghrelin signaling. Molecular Endocrinology 19 2400-2411. (doi:10.1210/me. 2005-0059)

Hosoda H, Kojima M, Matsuo H \& Kangawa K 2000 Ghrelin and des-acyl ghrelin: two major forms of rat ghrelin peptide in gastrointestinal tissue. Biochemical and Biophysical Research Communications 279 909-913. (doi:10.1006/bbrc.2000.4039)

Hosoda H, Kojima M \& Kangawa K 2006 Biological, physiological, and pharmacological aspects of ghrelin. Journal of Pharmacological Sciences 100 398-410. (doi:10.1254/jphs.CRJ06002X)

Howard AD, Feighner SD, Cully DF, Arena JP, Liberator PA, Rosenblum CI, Hamelin M, Hreniuk DL, Palyha OC, Anderson J et al. 1996 A receptor in pituitary and hypothalamus that functions in growth hormone release. Science 273 974-977. (doi:10.1126/science.273.5277.974)

Inhoff T, Wiedenmann B, Klapp BF, Mönnikes H \& Kobelt P 2009 Is desacyl ghrelin a modulator of food intake? Peptides 30 991-994. (doi:10.1016/ j.peptides.2009.01.019)

Jaillon O, Aury JM, Brunet F, Petit JL, Stange-Thomann N, Mauceli E, Bouneau L, Fischer C, Ozouf-Costaz C, Bernot A et al. 2004 Genome duplication in the teleost fish Tetraodon nigroviridis reveals the early vertebrate proto-karyotype. Nature 431 946-957. (doi:10.1038/ nature03025)

Kageyama H, Funahashi H, Hirayama M, Takenoya F, Kita T, Kato S, Sakurai J, Lee EY, Inoue S, Date Y et al. 2005 Morphological analysis of ghrelin and its receptor distribution in the rat pancreas. Regulatory Peptides 126 67-71. (doi:10.1016/j.regpep.2004.08.031)

Kaiya H, Kojima M, Hosoda H, Koda A, Yamamoto K, Kitajima Y, Matsumoto M, Minamitake Y, Kikuyama S \& Kangawa K 2001 Bullfrog ghrelin is modified by $n$-octanoic acid at its third threonine residue. Journal of Biological Chemistry 276 40441-40448. (doi:10.1074/jbc. M105212200)

Kaiya H, Miyazato M, Kangawa K, Peter RE \& Unniappan S 2008 Ghrelin: a multifunctional hormone in non-mammalian vertebrates. Comparative Biochemistry and Physiology. Part A, Molecular \& Integrative Physiology 149 109-128. (doi:10.1016/j.cbpa.2007.12.004)

Kaiya H, Mori T, Miyazato M \& Kangawa K 2009a Ghrelin receptor (GHS-R)like receptor and its genomic organisation in rainbow trout, Oncorhynchus mykiss. Comparative Biochemistry and Physiology. Part A, Molecular \& Integrative Physiology 153 438-450. (doi:10.1016/j.cbpa.2009.04.612)

Kaiya H, Riley LG, Janzen W, Hirano T, Grau EG, Miyazato M \& Kangawa K $2009 b$ Identification and genomic sequence of a ghrelin receptor (GHS-R)-like receptor in the Mozambique tilapia, Oreochromis mossambicus. Zoological Science 26 330-337. (doi:10.2108/zsj.26.330)

Kaiya H, Kodama S, Ishiguro K, Matsuda K, Uchiyama M, Miyazato M \& Kangawa K 2009c Ghrelin-like peptide with fatty acid modification and $O$-glycosylation in the red stingray, Dasyatis akajei. BMC Biochemistry 10 30. (doi:10.1186/1471-2091-10-30)

Kaiya H, Miura T, Matsuda K, Miyazato M \& Kangawa K 2010 Two functional growth hormone secretagogue receptor (ghrelin receptor) type 1a and 2a in goldfish, Carassius auratus. Molecular and Cellular Endocrinology 327 25-39. (doi:10.1016/j.mce.2010.06.004)

Kaiya H, Koizumi Y, Konno N, Yamamoto K, Uchiyama M, Kangawa K \& Miyazato M 2011a Ghrelin receptor in two species of Anuran
Amphibian, Bullfrog (Rana catesbeiana), and Japanese tree frog (Hyla japonica). Frontiers in Endocrinology 2 31. (doi:10.3389/fendo. 2011.00031)

Kaiya H, Miyazato M \& Kangawa K $2011 b$ Recent advances in the phylogenetic study of ghrelin. Peptides 32 2155-2174. (doi:10.1016/ j.peptides.2011.04.027)

Kaiya H, Kangawa K \& Miyazato M 2013a Ghrelin receptors in nonmammalian vertebrates. Frontiers in Endocrinology 4 81. (doi:10.3389/ fendo.2013.00081)

Kaiya H, Kangawa K \& Miyazato M 2013b What is the general action of ghrelin for vertebrates? - comparisons of ghrelin's effects across vertebrates General and Comparative Endocrinology 181 187-191. (doi:10.1016/j.ygcen.2012.10.015)

Kitazawa T, Maeda Y \& Kaiya H 2009 Molecular cloning of growth hormone secretagogue-receptor and effect of quail ghrelin on gastrointestinal motility in Japanese quail. Regulatory Peptides 158 132-142. (doi:10.1016/j.regpep.2009.07.005)

Kitazawa T, Nakamura T, Saeki A, Teraoka H, Hiraga T \& Kaiya H 2011 Molecular identification of ghrelin receptor (GHS-R1a) and its functional role in the gastrointestinal tract of the guinea-pig. Peptides 32 1876-1886. (doi:10.1016/j.peptides.2011.07.026)

Kohno D, Gao HZ, Muroya S, Kikuyama S \& Yada T 2003 Ghrelin directly interacts with neuropeptide-Y-containing neurons in the rat arcuate nucleus: $\mathrm{Ca}^{2+}$ signaling via protein kinase $\mathrm{A}$ and $\mathrm{N}$-type channel-dependent mechanisms and cross-talk with leptin and orexin. Diabetes 52 948-956. (doi:10.2337/diabetes.52.4.948)

Kojima M \& Kangawa K 2005 Ghrelin: structure and function. Physiological Reviews 85 495-522. (doi:10.1152/physrev.00012.2004)

Kojima M \& Kangawa K 2010 Ghrelin: more than endogenous growth hormone secretagogue. Annals of the New York Academy of Sciences 1200 140-148. (doi:10.1111/j.1749-6632.2010.05516.x)

Kojima M, Hosoda H, Date Y, Nakazato M, Matuso H \& Kangawa K 1999 Ghrelin is a growth-hormone-releasing acylated peptide. Nature $\mathbf{4 0 2}$ 656-660. (doi:10.1038/45230)

Kojima M, Ida T \& Sato T 2008 Structure of mammalian and nonmammalian ghrelins. Vitamins and Hormones 77 31-46. (doi:10.1016/S0083-6729(06)77003-0)

Lania A, Ballare E, Corbetta S, Filopanti M, Persani L \& Spada A 1998 Growth hormone-releasing hexapeptide (GHRP-6) increases intracellular calcium concentrations in cultured cells from human pituitary adenomas of different types. European Journal of Endocrinology 139 343-348. (doi:10.1530/eje.0.1390343)

Leggatt RA \& Iwama GK 2003 Occurrence of polyploidy in the fishes. Reviews in Fish Biology and Fisheries 13 237-246. (doi:10.1023/B:RFBF. 0000033049.00668.fe)

Leung PK, Chow KB, Lau PN, Chu KM, Chan CB, Cheng CH \& Wise H 2007 The truncated ghrelin receptor polypeptide (GHS-R1b) acts as a dominant-negative mutant of the ghrelin receptor. Cellular Signalling 19 1011-1022. (doi:10.1016/j.cellsig.2006.11.011)

Lei T, Buchfelder M, Fahlbusch R \& Adams EF 1995 Growth hormone releasing peptide (GHRP-6) stimulates phosphatidylinositol (PI) turnover in human pituitary somatotroph cells. Journal of Molecular Endocrinology 14 135-138. (doi:10.1677/jme.0.0140135)

Liu G, Fortin JP, Beinborn M \& Kopin AS 2007 Four missense mutations in the ghrelin receptor result in distinct pharmacological abnormalities. Journal of Pharmacology and Experimental Therapeutics 322 1036-1043. (doi:10.1124/jpet.107.123141)

Malagón MM, Luque RM, Ruiz-Guerrero E, Rodríguez-Pacheco F, García-Navarro S, Casanueva FF, Gracia-Navarro F \& Castaño JP 2003 Intracellular signaling mechanisms mediating ghrelin-stimulated growth hormone release in somatotropes. Endocrinology 144 5372-5380. (doi:10.1210/en.2003-0723)

Matsumoto M, Hosoda H, Kitajima Y, Morozumi N, Minamitake Y, Tanaka S, Matsuo H, Kojima M, Hayashi Y \& Kangawa K 2001 Structure-activity relationship of ghrelin: pharmacological study of 
ghrelin peptides. Biochemical and Biophysical Research Communications 287 142-146. (doi:10.1006/bbrc.2001.5553)

Meyer A \& Schartl M 1999 Gene and genome duplications in vertebrates: the one-to-four (-to-eight in fish) rule and the evolution of novel gene functions. Current Opinion in Cell Biology 11 699-704. (doi:10.1016/ S0955-0674(99)00039-3)

Mitchell V, Bouret S, Beauvillain JC, Schilling A, Perret M, Kordon C \& Epelbaum J 2001 Comparative distribution of mRNA encoding the growth hormone secretagogue-receptor (GHS-R) in Microcebus murinus (Primate, lemurian) and rat forebrain and pituitary. Journal of Comparative Neurology 429 469-489. (doi:10.1002/1096-9861 (20010115) 429:3 < 469::AID-CNE8 > 3.0.CO;2-)

Murphy WJ, Eizirik E, O’Brien SJ, Madsen O, Scally M, Douady CJ, Teeling E, Ryder OA, Stanhope MJ, de Jong WW et al. 2001a Resolution of the early placental mammal radiation using Bayesian phylogenetics. Science 294 2348-2351. (doi:10.1126/science.1067179)

Murphy WJ, Eizirik E, Johnson WE, Zhang YP, Ryder OA \& O'Brien SJ $2001 b$ Molecular phylogenetics and the origins of placental mammals. Nature 409 614-618. (doi:10.1038/35054550)

Nie Q, Fang M, Xie L, Peng X, Xu H, Luo C, Zhang D \& Zhang X 2009 Molecular characterization of the ghrelin and ghrelin receptor genes and effects on fat deposition in chicken and duck. Journal of Biomedicine \& Biotechnology 2009 567120. (doi:10.1155/2009/567120)

Nishi Y, Yoh J, Hiejima H \& Kojima M 2011 Structures and molecular forms of the ghrelin-family peptides. Peptides 32 2175-2182. (doi:10.1016/ j.peptides.2011.07.024)

Nishihara H, Maruyama S \& Okada N 2009 Retroposon analysis and recent geological data suggest near-simultaneous divergence of the three superorders of mammals. PNAS 106 5235-5240. (doi:10.1073/ pnas.0809297106)

Olsson C, Holbrook JD, Bompadre G, Jönsson E, Hoyle CH, Sanger GJ, Holmgren S \& Andrews PL 2008 Identification of genes for the ghrelin and motilin receptors and a novel related gene in fish, and stimulation of intestinal motility in zebrafish (Danio rerio) by ghrelin and motilin. General and Comparative Endocrinology 155 217-226. (doi:10.1016/ j.ygcen.2007.05.016)

Palyha OC, Feighner SD, Tan CP, McKee KK, Hreniuk DL, Gao YD, Schleim KD, Yang L, Morriello GJ, Nargund R et al. 2000 Ligand activation domain of human orphan growth hormone (GH) secretagogue receptor (GHS-R) conserved from Pufferfish to humans. Molecular Endocrinololy 14 160-169. (doi:10.1210/me.14.1.160)

Rediger A, Piechowski CL, Yi CX, Tarnow P, Strotmann R, Grüters A, Krude H, Schöneberg T, Tschöp MH, Kleinau G et al. 2011 Mutually opposite signal modulation by hypothalamic heterodimerization of ghrelin and melanocortin-3 receptors. Journal of Biological Chemistry 86 39623-39631. (doi:10.1074/jbc.M111.287607)

Rennison DJ, Owens GL \& Taylor JS 2012 Opsin gene duplication and divergence in ray-finned fish. Molecular Phylogenetics and Evolution 62 986-1008. (doi:10.1016/j.ympev.2011.11.030)

Richards MP \& McMurtry JP 2010 The avian proghrelin system. International Journal of Peptides 2010 749401. (doi:10.1155/2010/749401)

Richards MP, Poch SM \& McMurtry JP 2006 Characterization of turkey and chicken ghrelin genes, and regulation of ghrelin and ghrelin receptor mRNA levels in broiler chickens. General and Comparative Endocrinology 145 298-310. (doi:10.1016/j.ygcen.2005.09.013)

Saito E-S, Kaiya H, Tachibana T, Tomonaga S, Denbow DM, Kangawa K \& Furuse M 2005 Inhibitory effect of ghrelin on food intake is mediated by the corticotropin-releasing factor system in neonatal chicks. Regulatory Peptides 125 201-208. (doi:10.1016/j.regpep.2004.09.003)

Schellekens H, Dinan TG \& Cryan JF 2013 Taking two to tango: a role for ghrelin receptor heterodimerization in stress and reward. Frontiers in Neuroscience $\mathbf{7} 148$.
Sirotkin AV, Grossmann R, Maria-Peon MT, Roa J, Tena-Sempere M \& Klein S 2006 Novel expression and functional role of ghrelin in chicken ovary. Molecular and Cellular Endocrinology 257-258 15-25. (doi:10. 1016/j.mce.2006.06.004)

Small BC, Quiniou SM \& Kaiya H 2009 Sequence, genomic organization and expression of two channel catfish, Ictalurus punctatus, ghrelin receptors. Comparative Biochemistry and Physiology. Part A, Molecular \& Integrative Physiology 154 451-464. (doi:10.1016/j.cbpa.2009.07.027)

Sun Y, Garcia JM \& Smith RG 2007 Ghrelin and growth hormone secretagogue receptor expression in mice during aging. Endocrinology 148 1323-1329. (doi:10.1210/en.2006-0782)

Tachibana T, Tanaka M \& Kaiya H 2011 Central injection of des-acyl chicken ghrelin does not affect food intake in chicks. General and Comparative Endocrinology 171 183-188. (doi:10.1016/j.ygcen.2011.01.008)

Takahashi K, Furukawa C, Takano A, Ishikawa N, Kato T, Hayama S, Suzuki C, Yasui W, Inai K, Sone S et al. 2006 The neuromedin U-growth hormone secretagogue receptor $1 \mathrm{~b} /$ neurotensin receptor 1 oncogenic signaling pathway as a therapeutic target for lung cancer. Cancer Research 66 9408-9419. (doi:10.1158/0008-5472.CAN-06-1349)

Tanaka M, Miyazaki T, Yamamoto I, Nakai N, Ohta Y, Tsushima N, Wakita M \& Shimada K 2003 Molecular characterization of chicken growth hormone secretagogue receptor gene. General and Comparative Endocrinology 134 198-202. (doi:10.1016/S0016-6480(03)00247-8)

Tang XL, Wang Y, Li DL, Luo J \& Liu MY 2012 Orphan G protein-coupled receptors (GPCRs): biological functions and potential drug targets. Acta Pharmacologica Sinica 33 363-371. (doi:10.1038/aps.2011.210)

Tannenbaum GS \& Bowers CY 2001 Interactions of growth hormone secretagogues and growth hormone-releasing hormone/somatostatin. Endocrine 14 21-27. (doi:10.1385/ENDO:14:1:021)

Toshinai K, Yamaguchi H, Sun Y, Smith RG, Yamanaka A, Sakurai T, Date Y, Mondal MS, Shimbara T, Kawagoe T et al. 2006 Des-acyl ghrelin induces food intake by a mechanism independent of the growth hormone secretagogue receptor. Endocrinology 147 2306-2314. (doi:10.1210/ en.2005-1357)

Ueberberg B, Unger N, Saeger W, Mann K \& Petersenn S 2009 Expression of ghrelin and its receptor in human tissues. Hormone and Metabolic Research 1 814-821. (doi:10.1055/s-0029-1233462)

Verhulst PJ \& Depoortere I 2012 Ghrelin's second life: from appetite stimulator to glucose regulator. World Journal of Gastroenterology 18 3183-3195. (doi:10.3748/wjg.v18.i25.3183)

Wettschureck N, Moers A, Wallenwei B, Parlow AF, Maser-Gluth C \& Offermanns S 2005 Loss of Gq/11 family G proteins in the nervous system causes pituitary somatotroph hypoplasia and dwarfism in mice. Molecular and Cellular Biology 25 1942-1948. (doi:10.1128/МСB.25.5. 1942-1948.2005)

Yamamoto I, Yoshimura Y, Tsukada A, Kansaku N, Tsushima N \& Tanaka M 2008 Predominant expression of growth hormone secretagogue receptor in the caudal lobe of chicken pituitary and parallel development increase in expression of pituitary GH and proventriculus ghrelin mRNA. Animal Science Journal 79 116-121. (doi:10.1111/j.17400929.2007.00506.x)

Yang J, Brown MS, Liang G, Grishin NV \& Goldstein JL 2008 Identification of the acyltransferase that octanoylates ghrelin, an appetite-stimulating peptide hormone. Cell 132 387-396. (doi:10.1016/j.cell.2008.01.017)

Zaccone D, Sengar M, Lauriano ER, Pergolizzi S, Macri' F, Salpietro L, Favaloro A, Satora L, Dabrowski K \& Zaccone G 2012 Morphology and innervation of the teleost physostome swim bladders and their functional evolution in non-teleostean lineages. Acta Histochemica $\mathbf{1 1 4}$ 763-772. (doi:10.1016/j.acthis.2012.01.003)

Zigman JM, Jones JE, Lee CE, Saper CB \& Elmquist JK 2006 Expression of ghrelin receptor mRNA in the rat and the mouse brain. Journal of Comparative Neurology 494 528-548. (doi:10.1002/cne.20823)

Received in final form 24 November 2013

Accepted 17 December 2013

Accepted Preprint published online 18 November 2013 http://jme.endocrinology-journals.org DOI: 10.1530/JME-13-0175
() 2014 Society for Endocrinology Printed in Great Britain
Published by Bioscientifica Ltd 